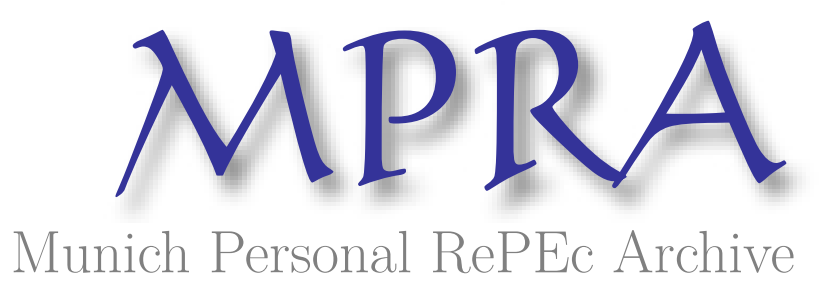

\title{
Financial Development and Money Demand Function: Cointegration, Causality and Variance Decomposition Analysis for Pakistan.
}

\author{
Ahad, Muhammad \\ COMSATS Institute of Information Technology, Lahore Campus, \\ Pakistan
}

2015

Online at https://mpra.ub.uni-muenchen.de/70033/

MPRA Paper No. 70033, posted 19 Mar 2016 10:07 UTC 


\title{
FINANCIAL DEVELOPMENT AND MONEY DEMAND FUNTION: COINTEGRATION, CAUSALITY AND VARIANCE DECOMPOSION ANALYSIS FOR PAKISTAN
}

\author{
Muhammad Ahad*1
}

\begin{abstract}
This study has investigated money demand function incorporating financial development, industrial production, income and exchange rate over the period of 1972-2012 for Pakistan. The newly introduced cointegration approach (Bayer-Hanck combined cointegration) and Johansen cointegration approach have been used to test cointegration among variables. The Vector Error Correction Model (VECM) model has applied to explain the direction of causality in the long run and short run. The Unit root problem has been tested by ADF and PP unit root tests. The results reveal that long run relationship exists between money demand, financial development, income, industrial production and exchange rate. Financial development is the main factor to determine the money demand function in both long and short run. The results indicate that feedback effect is found between financial development and money demand.
\end{abstract}

Keywords: Financial Development, Money demand, Cointegration, Causality, Pakistan

JEL Classification: E41, C1

\section{Introduction}

The demand for money is very important factor to explain monetary policy. Monitory aggregates play a vital role in monetary policy implications. The determinants of monetary aggregates such as real GDP, foreign exchange rates and inflation are very important that affect money demand. A stable demand function for money means the quantity of money is affected by a small set of key variables linking money to real sector of an economy (Judd and Scadding, 1982; Friedman, 1987). The empirical investigation of money demand function has been one of the most important topics in macroeconomics for a long time [Canova (2006), Lyoboyi and Pedro (2013), Samreth (2008), Omer (2010), Bhatta (2011)]

The demand for money is related to holding of financial assets in the form of money that can be in cash or bank deposits. It includes $\mathrm{M}_{0}$ defined as reserve money, $\mathrm{M}_{1}$ defined as narrow money, $\mathrm{M}_{2}$ and $\mathrm{M}_{3}$ defined as broader money. $\mathrm{M}_{0}$ is a sum of currency in circulation, deposit with State Bank of Pakistan, currency in till of scheduled bank and bank deposit with State Bank of Pakistan. $\mathrm{M}_{1}$ is narrow money includes currency in circulation, other deposit with State Bank of Pakistan and scheduled banks demand deposits. It provides liquidity means necessary carry out transections. It creates a trade-off between the liquidity advantage of holding money and the

\footnotetext{
* Research scholar

${ }^{1}$ Department of Management Science, COMSATS Institute of Information Technology, Lahore campus,

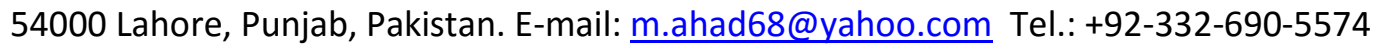


interest advantage of holding other assets. $\mathbf{M}_{2}$ is broad money includes narrow money $\left(\mathbf{M}_{1}\right)$ and scheduled bank time deposits.

Currency in circulation was 261.5 billion rupees in 2012-2013 as compare to 170.5 billion rupees in 2011-2012. When we compare currency in circulation with money supply, it has increased from $23.0 \%$ to $23.2 \%$ respectively. The currency in circulation has increased due to higher cash demand with an increase in growth of agriculture sector and higher cash transferred through Benazir Income Support Program (BISP). Broad money $\left(\mathrm{M}_{2}\right)$ has expanded to $9.9 \%$ during 2012-13 against the growth $9.1 \%$ in comparable period last year. The growth in $\mathrm{M}_{2}$ during 201213 is mainly contributed by the improvement in net foreign assets (NFA), rise in Net Domestic Assets (NDA) and credit off take by the Public Sector Enterprises (PSEs). The reserve money $\left(\mathrm{M}_{0}\right)$ grew $13.1 \%$ against the expansion of $9.6 \%$ in same period (Economic Survey of Pakistan, 2013). Motive of demand for money includes transection, precautionary and speculative. Transection motives deal with demand for money for the purpose of transection. When GDP rises the transactions demand for money also rise. Precautionary motives include demand for money for the purpose of unexpected expenses that require immediate payments. The speculative motives include demand for money to invest in assets which depends upon rate of return and opportunity cost. If risk of assets is less risky than demand for money will increase.

There are many studies which have estimated money demand function for Pakistan such as Mangla (1979), Qayyum (1998), Khan and Ali (1997) and Hussain et.al (2006). This paper aims to estimate money demand function with industrial production, financial development, income and exchange rate. Section 2 covers review of literature, section 3 covers model construction and data collection, section 4 explains empirical analysis and results interpretation and the last section will present conclusion and recommendation.

\section{Review of Literature:}

Numerous studies have investigated the stability of import demand function by applying various time series methods but provided inconclusive results. For example, Azim et al. (2010) estimated the demand for money by applying the ARDL bounds testing approach. The results showed that $\mathrm{M}_{2}$ is stable for time period of 1973-2007. Inflation and income has positive and exchange rate has negative effect on money demand. Inoue and Hamori, (2009) examined the money demand function for India by applying Johansen cointegration approach. The results predicted that cointegration exist only when we use $\mathrm{M}_{2}$ as money demand otherwise there is no cointegration. Dogru, (2013) investigated the stability of money demand function for case of Turkey. Johansen cointegration has confirmed the long run cointegration relationship amid money demand, income and interest rate. On contrary, Sahin, (2013) revisited the money demand function for Turkey and found an asymmetric behavior and nonlinearity function. The results predicted that the stability of money demand function depends upon stability of inflation for monthly data from 1990 to 2012. Similarly, Halicioglu and Ugur, (2005) confirmed the stability of money demand $\left(\mathrm{M}_{1}\right)$ function in Turkey.

Quyyam, (2005) has confirmed instability of money demand $\left(\mathrm{M}_{2}\right)$ due to changes in bond yield, interest rate and market rate using time period from 1960 to 1999 for case of Pakistan. The oil shocks and exchange rate shifting effects have estimated for money demand by using inflation, rate of interest and price and nominal income ratio. Hiernaux et. al. (2006) analyzed money 
demand function using panel data from 1988 to 1998 for 27 countries. They have used Cagan theory as a base to find out relationship between real money, interest rate, and income. The results have confirmed the stable money demand function having positive relationship between income and money demand and negative relationship between interest rate. Canova, (2006) has examined money demand function for Jamaica. The ARDL model has confirmed instability in money demand function in short run due to fluctuation in government bonds yields. Interest rate and income has significant effect on money demand function in long run.

Lyoboyi and Pedro, (2013) probed the money demand function in case of Nigeria using time period 1970 to 2010. They have confirmed stability of $\mathbf{M}_{1}$ by using Chow breakpoint test, (CUSUM) and (CUSUMSQ) tests by incorporating real income, short term interest rate, real expected exchange rate, expected inflation rate and foreign real interest rate. Bhatta, (2011) examined the money demand functions for long run and short run for Nepal using the annual data set of 1975 to 2009 . The ARDL modeling to cointegration has used to analysis cointegration. The bounds test shows the exists of long run cointgration relationship among demand for real money balances, real GDP and interest rate in case of both narrow and broad monetary aggregates. Further, the CUSUM and CUSUM SQ test reveal that both the long run narrow and broad money demand functions are stable.

Khatiwada, (1997) investigated money demand function for Nepal and exhibited stable money demand function. Cointegration exit between $\mathrm{M}_{1}, \mathrm{M}_{2}$, real GDP, and interest rate. Similarly, Budha, (2011) also investigated money demand for Nepal and stated that velocity of $\mathrm{M}_{2}$ is more stable than $\mathrm{M}_{1}$ by using time period 1997 to 2010. Kahrel and Koirala, (2010) also confirmed stable money demand function for Nepal for time period 1975 to 2010 by taking $\mathrm{M}_{1}, \mathrm{M}_{2}$, Real GDP and interest rate. Anoruo, (2002) investigated money demand function in period of structural adjustment program using 1986:2 to 2000:1 data for Nigeria. The results of this investigation has provided the evidence of stability of money demand function. Moreover, the cointegration exist between Money $\left(\mathrm{M}_{2}\right)$, real discount rate, economic activity and real industrial production. Similarly, Aakinlo, (2006) also estimated money demand function for Nigeria using ARDL Model and cointegration technique for time period from 1970Q1 to 2002Q4 and provided the evidence of stable of money demand function by including $\mathrm{M}_{2}$, Real GDP, interest rate, and exchange rate.

Samreth, (2008) confirmed stable money demand function in Cambodia through CUSUM and CUSUMSQ test. Money demand/prices (M/P), real income level, opportunity cost variable, inflation and exchange rate, Political upheaval as a dummy variable (DU) have taken in this study. The analysis predicted that Exchange rate support currency substitution for the time period 1994:12 to 2006:12. George, (2002) has provided the evidence of instability for money demand function for Uganda using Quarterly data from 1981 to 1998. Results have shown that income and inflation has positive relationship with money demand and exchange rate and interest rate has negative relationship with money demand. Tillers, (2004) investigated the money demand function for Latvia using annually data from 1996-2003 and concluded his results by finding stable money demand function in Latvia. Money demand/prices (M/P), real income level, opportunity cost variable, inflation and exchange rate, Political upheaval as a dummy variable (DU) have summed up to estimate this study. The results predicted that money demand is highly income elastic. Due to rapid growth and stable money demand function rapid equilibrium adjustment exist. 
Omer, (2010) probed velocity of money demand function and its relationship with interest rate fluctuations by using data 1975 to 2006 for Pakistan. The results confirmed stable money demand function using velocity of money, real permanent income per capita, real interest rate, transitory income, and expected inflation. It showed that money velocity is independent from interest rate. Tang, (2007) reinvestigated money demand function for Japanese economy. Previous studies have shown stable money demand function by using CUSUM and CUSUM of square tests. In this paper ARDL results shows instability in money demand due to many changes in monetary policy of Japan. Kumar and Manoka, (2008) have tested the stability of money demand function for Tonga by using approaches of LSE Hendry's General to Specific (GETS) and Johansen's Maximum Likelihood (JML). The results predict that there Is a stable long run cointegrated relationship exist between real narrow money, real income and rate of interest.

Dumitru, (2002) confirmed the stability of money demand function for Romania and provided evidence for cointegration between Broad money $\left(\mathrm{M}_{3}\right)$, inflation, interest rate and real GDP using Johansen multivariate cointegration for time period 1996 to 2002. Brand and Cassola, (2000) incorporated the money demand function with inflation, short run and long run interest rate and real GDP for time period 1980Q1 to 1999Q3 in case of Euro area. It is confirmed that stable money demand function exists by using structural cointegration VAR approach. Taylor, (1993) provided its results of instability of money demand for UK by using Johansen MLE to cointegration in time period 1871 to 1913. Lumas and mehra, (1976) estimated the money demand model for USA and confirmed instability of money demand with the help of income and interest rate by using Quarterly data from 1900 to 1974. Hamori and hamori, (1999) also provided their results in favor of instability using data from 1969: Q1 to 1996: Q4 for Germany by combining real GDP, $\mathrm{M}_{1}, \mathrm{M}_{2}, \mathrm{M}_{3}$ and call rates. Similarly, other investigation of Japanese money demand function Oskooee, (2001) provided the results of stable money demand function using 1964Q1 to 1996Q4 time period for Japan. ARDL modeling has used to check the cointegration relationship between $\mathrm{M}_{2}$, real income, exchange rate and interest rate.

In case of Hong Kong, Oskooee and wing, (2002) have applied ARDL model to find the long run demand for money for 1985Q1 to 1999Q4 time period and concluded the stable money demand function uniting $\mathrm{M}_{2}$, real income, exchange rate and interest rate. Oskooee and rehman, (2005) probed the stability of money demand function in Asian developing countries using time period from 1972 Q1 to 2000 Q4. The results of this estimation were $\mathrm{M}_{1}$ is stable in India, Indonesia, and Singapore and M2 is stable in Malaysia, Pakistan, Philippines and Thailand. Oskooee and bahmani, (2007a) examined the impact of exchange rate velocity on money demand function in case of Iran. The results have shown that real GDP, inflation, exchange rate and velocity of exchange rate are four main determinants of stable money demand function. Ahmed and Ahmed and Islam, (2007) found cointegration between money demand, real income, and nominal interest rate and stated that money demand function is stable using Johansen cointegration approach for Bangladesh for 1990Q1 to 2006Q4 time period. Oskooee and wang, (2007b) found the stability of money demand in case of china. According to results $\mathrm{M}_{1}$ and $\mathrm{M}_{2}$ are cointegration with their determinants and $\mathrm{M}_{1}$ is stable but $\mathrm{M}_{2}$ is not stable.

Ashani, (2010) probed the stability of money demand function in an emerging market for Indonesia. ARDL confirmed the cointegration between $\mathrm{M}_{1}, \mathrm{M}_{2}$, permanent income and interest rate and stability of money demand function. Dreger and Wolters, (2014) probed the money 
demand function for unconventional monetary policy. This study has used time period from 1988Q1-2013Q4. Real money balance (money balances- price level), real income, real financial wealth, Opportunity costs of holding money (R), interest rates, inflation rate, and yield of money holdings have incorporated to test stability of money demand function. The results showed stable money demand and predicted that money balance is useful to establish monetary policy for US and Euro area. Sriram, (2001) has made a survey related to money demand papers that applied the error- correction models to analyze the demand for money in a number of industrial and developing countries. He concluded his study by finding different results for different countries by comparing ECM and stability test. Siliverstovs, (2007) exhibited money demand function for Estonia from 1995 to 2006 and provided results in favor of stable money demand function.

Sarwar et. al. (2011) revealed money demand function for Pakistan through Divisia approach using time period from 1972 to 2007 . The estimation of this study provided the stability of money demand function using $\mathrm{M}_{2}$, Consumer utility, consumption goods, leisure time, and service of monetary policy. Singh and Pandey, (2010) examined financial innovation and stability of money demand function in post-reform period in India for time period 1996-97:1 to 2009-10:3. Gregory-Hanson Cointegration Test and residual analysis of ECM equation test provided results that do not support stable money demand function. Sosunov, (2012) evaluated the money demand function for Russia using money stock/price as a dependent variable and income and interest rate as independent variables for time period 2003 to 2013. According to results money demand is stable in both long and short run. Hafer and Jansen, (1991) probed money demand function for US by testing data from 1915:1 to 1988:4 with cointegration test. The results of this study was $\mathrm{M}_{2}$ is preferable measure to consider long run economic impacts of changes in monetary policy.

Literature has pointed out many key determinates of money demand such as income, inflation, exchange rate, income ratio (y/p), shocks, short and long term domestic interest rate, foreign real interest rate, gold, share prices, industrial productions and political instability not only for Pakistan but also globally. We find from above discussion that existing studies in literature have ignored the role of financial development while investigating money demand function. This study fills the gap and improves the existing literature by investigating impact of financial development on money demand function for time period from 1972 to 2012. Financial development plays a vital role to stimulate money demand. Financial sectors provide finance to private sectors at low cost which helps to entrepreneurs to start their own business. As a result, the number of various intermediate goods increases, causing an increase in demand for final goods. Increase in high demand cause to increase in industrialization and development by increasing money demand (Shahbaz and Rahman, 2012).

\section{Methodology, Model Construction and Data Collection:}

This study has explored the relationship between financial development and money demand by incorporating industrial production, income and exchange rate for time series data from 1972 to 2012 for Pakistan. The general elasticity function is following:

$$
\begin{aligned}
& M_{t}=f\left(\operatorname{indp}_{t,} y_{t}, f d_{t,}, \text { exr }_{t}\right) \\
& M_{t}=\beta_{0}+\beta_{1} \text { indp }_{t}+\beta_{2} y_{t}+\beta_{3} f d_{t}+\beta_{4} \text { exr }_{t}+\mu_{t}
\end{aligned}
$$


Here, $M_{t}$ shows Money demand proxy by $\mathrm{M}_{2}$, ind $p_{t}$ shows industrial production index for industrial production, $y_{t}$ shows income proxy by Real GDP per capita, $f d_{t}$ is real domestic credit to private sector per capita proxy of financial development and $e x r_{t}$ shows exchange rate. All the series has transformed into logarithm to reduce sharpness into the data and to make model estimate. The transformed equation is as following:

$\ln M_{t}=\beta_{0}+\beta_{1} \ln i n d p_{t}+\beta_{2} \ln y_{t}+\beta_{3} \ln f d_{t}+\beta_{4} \ln e x r_{t}+\mu_{t}$

Here, $\ln M_{t}$ is natural $\log$ of Money demand, $\ln i n d p_{t}$ is natural $\log$ of industrial production, $\ln y_{t}$ is natural $\log$ of income, $\ln f d_{t}$ is natural $\log$ of real domestic credit to private sector per capita proxy of financial development, lnexr $t_{t}$ is natural log of exchange rate and $\mu_{t}$ is error term assumed to have normally distributed having zero mean and constant variance. Data has collected from State bank of Pakistan and International Financial Statistics (IFS). In the time series analysis, series are deceptively integrated if two or more series are individually integrated. To address the cointegration phenomenon, several techniques have been developed in time series literature. These techniques include Engle and Granger, (1987) cointegration approach, Johansen (1991) Johansen maximum Eigen value test, Phillips and Ouliaris (1990) Phillips-Ouliaris cointegration test and Error Correction Model (ECM) based F-test of Peter Boswijk (1994), and the ECM based t-test of Banerjee et al. (1998).

The Engle and Granger, (1987) cointegration approach, for instance requires stationary among non-stationary variables and useful for limited data set length. Similarly, Johansen (1991) maximum Eigen value test allow more than one co integrating vector and consider more flexible and generally applicable than Engle and Granger, (1987) test. I have applied Bayer-Hanck combined cointegration, Johansen cointegration, Error correction mechanism and Enger Granger approach to analysis relationship among variables.

However different tests provide different results. To enhance the power of cointegration test, Bayer and Hanck, (2013) suggested joint cointegration test for null of no cointegration based on Engle and Granger, Johansen, Peter Boswijk, and Banerjee tests. That's why, this technique called Bayer and Hanck, (2013) combined cointegration. This new approach allows us to combined all individual cointegration test results to provide more appropriate and conclusive results. It is also applied in this paper to investigate cointegration relationship between financial development and money demand function. Following Bayer and Hank (2013), the combination of the computed significance level ( $p$-value) of individual cointegration test in this paper is in Fisher's formulas as follows

$$
\begin{aligned}
& E G-J O H=-2\left[\ln \left(P_{E G}\right)+\left(P_{J O H}\right)\right] \\
& E G-J O H-B O-B D M=-2\left[\ln \left(P_{E G}\right)+\left(P_{J O H}\right)+\left(P_{B O}\right)+\left(P_{B D M}\right)\right]
\end{aligned}
$$

Where $P_{E G}, P_{J O H}, P_{B O}$ and $P_{B D M}$ are the p-values of various individual cointegration tests respectively. It is assumed that if the estimated Fisher statistics exceed the critical values provided by Bayer and Hanck (2013), the null hypothesis of no cointegration is rejected.

\section{Results and Discussion:}


Table-1 shows the results of descriptive statistics and correlation. Descriptive statistics explain mean, median and mode. Jarque-Bera shows that series of data is normally distributed having zero mean and constant variance. Correlation matrix shows that industrial production, income, financial development and exchange rate are positively correlated with money demand. Similarly, income, financial development and exchange are also positively correlated with industrial production. Financial development and exchange rate are positivity correlated with income. Exchange rate is also positively correlating with financial development. We need to check order of integration of Money demand, industrial production, income, financial development and exchange rate. There are many to check stationary of data such as ADF by Dicky and Fuller (1981), P-P by Philip and Perron (1988), DF-GLS by Elliot et al. (1996) and NG-Perron (2001). ADF and Philips-Perron test have applied to check whether the data is stationary or not. The results of ADF and Philips-Perron test have incorporated in table-2. According to results, data has unit root problem at level but at $1^{\text {st }}$ difference it is stationary. It means that all variables are integrate at I(1). Table-3 explains the results of VAR lag order criteria for optimal lag selection. This study has followed the result of AIC which shows that there are two optimal lag for appropriate estimation.

Table-1. Descriptive statistics and correlation matrix

\begin{tabular}{|l|l|l|l|l|l|}
\hline Variables & $\ln M 2_{t}$ & $\ln i n d p_{t}$ & $\ln y_{t}$ & $\ln f d_{t}$ & $\ln$ exr $_{t}$ \\
\hline Mean & 26.86722 & 23.26193 & 10.05956 & 4.217489 & 3.274189 \\
\hline Median & 26.94895 & 23.39074 & 10.15455 & 4.131480 & 3.222182 \\
\hline Maximum & 29.66465 & 24.29928 & 10.48687 & 5.995108 & 4.536840 \\
\hline Minimum & 23.81699 & 21.98352 & 9.549175 & 2.788708 & 2.161181 \\
\hline Std. Dev. & 1.724371 & 0.706450 & 0.289179 & 0.986332 & 0.792549 \\
\hline Skewness & -0.095419 & -0.235347 & -0.344012 & 0.401869 & 0.050116 \\
\hline Kurtosis & 1.866656 & 1.879495 & 1.910484 & 2.030535 & 1.521160 \\
\hline Jarque-Bera & 2.256517 & 2.836557 & 2.836557 & 2.709171 & 3.753234 \\
\hline Probability & 0.323596 & 0.283179 & 0.242130 & 0.258054 & 0.153107 \\
\hline $\ln M 2_{t}$ & 1.000000 & & & & \\
\hline $\ln$ ind $p_{t}$ & 0.995247 & 1.000000 & & & \\
\hline $\ln y_{t}$ & 0.987710 & 0.996998 & 1.000000 & & \\
\hline $\ln f d_{t}$ & 0.978751 & 0.969392 & 0.957768 & 1.000000 & \\
\hline $\ln$ exr $r_{t} 0.981411$ & 0.973304 & 0.962520 & 0.963380 & 1.000000 \\
\hline Source: Authors' estimation. & & & \\
\hline
\end{tabular}

Table-2: Unit root statistics

\begin{tabular}{|l|l|l|}
\hline Variables & ADF Unit Root Test & Phillips-Perron Test \\
\hline
\end{tabular}




\begin{tabular}{|l|l|l|l|l|l|l|}
\hline & $\begin{array}{l}\text { T-statistic } \\
\text { "Intercept } \\
\text { and trend" }\end{array}$ & $\begin{array}{l}\text { Prob. } \\
\text { Values }\end{array}$ & Decision & $\begin{array}{l}\text { T-statistic } \\
\text { "Intercept } \\
\text { and trend" }\end{array}$ & $\begin{array}{l}\text { Prob. } \\
\text { Values }\end{array}$ & Decision \\
\hline $\ln M 2_{t}$ & -2.4615 & 0.3443 & $\begin{array}{l}\text { Non- } \\
\text { Stationery }\end{array}$ & -2.1234 & 0.5175 & $\begin{array}{l}\text { Non- } \\
\text { Stationery }\end{array}$ \\
\hline $\ln i n d p_{t}$ & -1.0849 & 0.9191 & $\begin{array}{l}\text { Non- } \\
\text { Stationery }\end{array}$ & -1.3616 & 0.8570 & $\begin{array}{l}\text { Non- } \\
\text { Stationery }\end{array}$ \\
\hline $\ln y_{t}$ & -1.2436 & 0.8869 & $\begin{array}{l}\text { Non- } \\
\text { Stationery }\end{array}$ & -1.3011 & 0.8733 & $\begin{array}{l}\text { Non- } \\
\text { Stationery }\end{array}$ \\
\hline $\ln f d_{t}$ & -2.7285 & 0.2314 & $\begin{array}{l}\text { Non- } \\
\text { Stationery }\end{array}$ & -2.5445 & 0.3064 & $\begin{array}{l}\text { Non- } \\
\text { Stationery }\end{array}$ \\
\hline $\ln$ exr $r_{t}$ & -1.8970 & 0.6374 & $\begin{array}{l}\text { Non- } \\
\text { Stationery }\end{array}$ & -2.0711 & 0.5455 & $\begin{array}{l}\text { Non- } \\
\text { Stationery }\end{array}$ \\
\hline$\Delta \ln M 2 t$ & $-4.3508^{*}$ & 0.0070 & Stationery & $-4.3400^{*}$ & 0.0072 & Stationery \\
\hline$\Delta \ln$ indpt & $-4.9988^{*}$ & 0.0012 & Stationery & $-4.9888^{*}$ & 0.0013 & Stationery \\
\hline$\Delta \ln Y t$ & $-4.8411^{*}$ & 0.0019 & Stationery & $-4.8910^{*}$ & 0.0017 & Stationery \\
\hline$\Delta \ln f d t$ & $-4.1709^{* *}$ & 0.0111 & Stationery & $-4.1314 * *$ & 0.0122 & Stationery \\
\hline$\Delta \ln$ exrt & $-4.7179^{*}$ & 0.0027 & Stationery & $-4.7662^{*}$ & 0.0023 & Stationery \\
\hline $\begin{array}{l}\text { Source: Authors' estimation. } \\
\text { Note: significance at } 1 \% \text { and } 5 \% \text { is shown by *and ** respectively. }\end{array}$ \\
\hline
\end{tabular}

Table-3: lag length criteria

\begin{tabular}{|c|c|c|c|c|c|c|}
\hline \multicolumn{7}{|c|}{ VAR Lag Order Selection Criteria } \\
\hline Lag & $\operatorname{LogL}$ & LR & FPE & AIC & $\mathrm{SC}$ & $\mathrm{HQ}$ \\
\hline 0 & 125.2334 & NA & $1.23 \mathrm{e}-09$ & -6.328075 & -6.112603 & -6.251411 \\
\hline 1 & 396.0134 & 456.0504* & $3.00 \mathrm{e}-15^{*}$ & -19.26386 & $-17.97103^{*}$ & $-18.80388^{*}$ \\
\hline 2 & 421.4523 & 36.15013 & $3.15 \mathrm{e}-15$ & $-19.28697 *$ & -16.91677 & -18.44367 \\
\hline 3 & 439.1126 & 20.44868 & $5.63 \mathrm{e}-15$ & -18.90066 & 15.45311 & -17.67405 \\
\hline \multicolumn{7}{|c|}{ * indicates lag order selected by the criterion. } \\
\hline $\begin{array}{l}\text { LR: } \\
\text { FPE: } \\
\text { AIC: } \\
\text { SC: S } \\
\text { HQ: }\end{array}$ & $\begin{array}{l}\text { lential moc } \\
\text { al predicti } \\
\text { aike inforn } \\
\text { warz inforr } \\
\text { inan-Quin }\end{array}$ & $\begin{array}{l}\text { ed LR test s } \\
\text { error } \\
\text { ion criterior } \\
\text { ion criterio } \\
\text { formation c }\end{array}$ & tistic (each & st at $5 \%$ leve & & \\
\hline
\end{tabular}

Source: Authors' estimation.

This study has applied Bayer-Hanck combined cointegration and Johansen cointegration test because series of data is integrating at $1^{\text {st }}$ difference or $I(1)$. The results of Bayer-Hanck combined cointegration are reported in table-4. The computed Fisher-statistics for EG-JOH and EG-JOH-BO-BDM tests exceed critical values at 1 percent level of significance. This seems to 
reject the hypothesis of no cointegration between variables. This shows that there is a long run relationship among the variables. The results of Johansen cointegration has shown in table-5. According to Trace statistics, two cointegrating vectors exist but maximum Eigen value shows that there is only one cointegrating vector. So, these results have confirmed cointeration among variables.

Table-4 Bayer and Hanck combined cointegration test

\begin{tabular}{|c|c|c|c|}
\hline Estimated model & EG-JOH & $\begin{array}{l}\text { EG-JOH-BO- } \\
\text { BDM }\end{array}$ & Cointegration \\
\hline$M_{t}=f\left(\right.$ indp $_{t}, y_{t}, f d_{t}$, exr $\left._{t}\right)$ & $58.43348^{*}$ & $65.48806^{*}$ & Yes \\
\hline $\operatorname{ind}_{t}=f\left(M_{t}, y_{t}, f d_{t}\right.$, exr $\left._{t}\right)$ & $55.88271 *$ & $69.70817 *$ & Yes \\
\hline$y_{t}=f\left(\right.$ indp $\left._{t}, M_{t}, f d_{t}, \operatorname{exr}_{t}\right)$ & $55.37476 *$ & $111.4116^{*}$ & Yes \\
\hline$f d_{t,}=f\left(\right.$ indp $_{t}, y_{t}, M_{t}$, exr $\left._{t}\right)$ & $55.36505^{*}$ & $72.29786^{*}$ & Yes \\
\hline$e x r_{t}=f\left(i n d p_{t}, y_{t}, f d_{t}, M_{t}\right)$ & $56.87960 *$ & 92.33467* & Yes \\
\hline \multicolumn{4}{|c|}{$\begin{array}{l}\text { *Represents significant at } 1 \% \text { level. Critical values at } 1 \% \text { level are } 15.845 \\
\text { for (EG-JOH) and } 30.774 \text { for (EG-JOH-BO-BDM). Lag length is based } \\
\text { on minimum value of AIC. } \\
\text { Source: Author's estimations }\end{array}$} \\
\hline
\end{tabular}

Table-5: Johansen cointegration:

\begin{tabular}{|l|l|l|}
\hline Hypothesis & $\begin{array}{l}\text { Trace } \\
\text { statistics }\end{array}$ & $\begin{array}{l}\text { Maximum } \\
\text { Eigen value }\end{array}$ \\
\hline $\mathrm{R}=0$ & $112.7534^{*}$ & $41.55254^{* *}$ \\
\hline $\mathrm{R} \leq 1$ & $71.20082^{* *}$ & 30.20965 \\
\hline $\begin{array}{l}\text { Note: significance at 1\% and 5\% is } \\
\text { shown by * and ** respectively. }\end{array}$ \\
\hline Source: Authors' estimation. \\
\hline
\end{tabular}

Table-6 shows long run relationship between money demand, industrial production, income, financial development and exchange rate. The results explain that industrial production, financial development, exchange rate have positive significant impact on money demand. But income has negative significant impact on money demand. It means that $1 \%$ increase in industrial production, financial development and exchange rate will lead to increase in money demand by $2.76 \%, 0.22 \%$ and $0.29 \%$ respectively. It means that when exchange rate will increase, currency will depreciate and more money have needed in economy. Similarly, $1 \%$ increase in income will lead to decrease in money demand by $2.34 \%$. R-squared shows that $99 \%$ dependent variable is explaining by independent variables. Overall model is significant because F-statistics is significant at $1 \%$.

\section{Table-6: Long Run Analysis}




\begin{tabular}{|l|l|l|l|}
\hline \multicolumn{4}{|l|}{ Dependent Variable: $\ln M 2_{t}$} \\
\hline Constant & Coefficient & Std. error & T-statistics \\
\hline $\ln i n d p_{t}$ & $2.760372^{*}$ & 0.507504 & 5.439117 \\
\hline $\ln y_{t}$ & $-2.347247^{* *}$ & 0.990289 & -2.370266 \\
\hline $\ln f d_{t}$ & $0.228559^{* *}$ & 0.087744 & 2.604847 \\
\hline $\ln$ exr $_{t}$ & $0.290789^{* *}$ & 0.115758 & 2.512041 \\
\hline R-squared & 0.995835 & & \\
\hline F-statistic & $2151.850^{*}$ & \\
\hline Prob. & 0.000000 \\
\hline $\begin{array}{l}\text { Source: Authors' estimation. } \\
\text { Note: significance at 1\% and 5\% is shown by * and ** respectively. }\end{array}$ \\
\hline
\end{tabular}

Table-7 shows the results of short run analysis. Only financial development has positive significant impact on money demand. Industrial production has positive insignificant impact on money demand. Income and exchange rate have negative insignificant impact on money demand. It means that to control money demand in short run, we need to control financial development. The coefficient of lagged ECM in negative but insignificant. It means that negative sign shows speed of adjustment from disequilibrium to equilibrium. Lagged ECM suggest that change in money demand from short run to long run will take 8.17 percent per year for Pakistan.

The existence of cointegration between money demand, industrial production, income, financial development and exchange rate lead us to apply Granger causality test to perform clear picture of causality relationship among variables. The results of VECM granger causality has reported in table-8. The direction of causality can be divided into short run and long run causality. The results show that money demand causes financial development in short run only but financial development cause money demand both in short and long run. So we can say that bidirectional causality exists between financial development and money demand. Industrial production cause income and income also cause industrial production in both short and long run. Exchange rate cause money demand in both short and long run but money demand does not cause exchange rate. So, unidirectional causality exists between money demand and exchange rate. Exchange rate cause income in both short and long run and income does not cause exchange rate in short run but cause in long run.

Table-7: Short Run Analysis

\begin{tabular}{|l|l|l|l|}
\hline \multicolumn{4}{|l|}{ Dependent Variable: $\ln M 2_{t}$} \\
\hline Constant & Coefficient & Std. error & T-statistics \\
\hline $\ln i n d p_{t}$ & 0.373960 & 0.244528 & 1.529316 \\
\hline $\ln y_{t}$ & -0.162129 & 0.473319 & -0.342536 \\
\hline $\ln f d_{t}$ & $0.206782 * *$ & 0.085777 & 2.410698 \\
\hline $\ln e x r_{t}$ & -0.138776 & -0.120923 & -1.147627 \\
\hline$E C M_{t-1}$ & -0.081735 & 0.065115 & -1.255236 \\
\hline R-squared & 0.300276 & & \\
\hline
\end{tabular}




\begin{tabular}{|l|l|}
\hline F-statistics & $2.918123 * *$ \\
\hline Prob. & 0.026875 \\
\hline Source: Authors' estimation. \\
Note: significance at $1 \%$ and $5 \%$ is shown by $*$ and $* *$ respectively. \\
\hline
\end{tabular}

Table-8: VECM Granger causality analysis

\begin{tabular}{|c|c|c|c|c|c|c|}
\hline \multirow{2}{*}{$\begin{array}{l}\text { Dependent } \\
\text { variables }\end{array}$} & \multicolumn{5}{|l|}{ Short Run } & \multirow{2}{*}{$\begin{array}{l}\text { Long Run } \\
E C M_{t-1}\end{array}$} \\
\hline & $\ln M 2_{t}$ & $\ln i n d p_{t}$ & $\ln y_{t}$ & $\ln f d_{t}$ & $\ln \operatorname{exr}_{t}$ & \\
\hline $\ln M 2_{t}$ & --- & $\begin{array}{l}0.916267 \\
(0.4117)\end{array}$ & $\begin{array}{l}0.040225 \\
(0.9606)\end{array}$ & $\begin{array}{l}4.296654 * * \\
(0.0236)\end{array}$ & $\begin{array}{l}0.641095 \\
(0.5343)\end{array}$ & $\begin{array}{l}-0.093129 \\
(0.1955)\end{array}$ \\
\hline $\ln i n d p_{t}$ & $\begin{array}{l}0.770496 \\
(0.4723)\end{array}$ & --- & $\begin{array}{l}8.583238^{*} \\
(0.0012)\end{array}$ & $\begin{array}{l}1.116346 \\
(0.3416)\end{array}$ & $\begin{array}{l}2.091664 \\
(0.1424)\end{array}$ & $\begin{array}{l}-0.658026^{*} \\
(0.0037)\end{array}$ \\
\hline $\ln y_{t}$ & $\begin{array}{l}0.220151 \\
(0.8038)\end{array}$ & $\begin{array}{l}8.982172 * \\
(0.0010)\end{array}$ & --- & $\begin{array}{l}1.260637 \\
(0.2991)\end{array}$ & $\begin{array}{l}0.531630 \\
(0.5935)\end{array}$ & $\begin{array}{l}-0.547071 * * \\
(0.0114)\end{array}$ \\
\hline $\ln f d_{t}$ & $\begin{array}{l}4.329514 * * \\
(0.0230)\end{array}$ & $\begin{array}{l}1.604899 \\
(0.2188)\end{array}$ & $\begin{array}{l}2.179158 \\
(0.1320)\end{array}$ & $\begin{array}{c}-- \\
-1\end{array}$ & $\begin{array}{l}1.801303 \\
(0.1837)\end{array}$ & $\begin{array}{l}-0.161276^{* *} \\
(0.0156)\end{array}$ \\
\hline $\ln e x r_{t}$ & $\begin{array}{l}2.846574 * * * \\
(0.0749)\end{array}$ & $\begin{array}{l}0.211555 \\
(0.8106)\end{array}$ & $\begin{array}{l}3.750100 * * \\
(0.0361)\end{array}$ & $\begin{array}{l}0.268367 \\
(0.7666)\end{array}$ & --- & $\begin{array}{l}-0.285641^{*} \\
(0.0003)\end{array}$ \\
\hline \multicolumn{7}{|c|}{ Source: Authors' estimation. } \\
\hline
\end{tabular}

Variance Decomposition Approach is better than Granger causality approach. The variance decomposition approach indicates the magnitude of predicted error variance for a series accounted for by innovations from each of the independent variable over different time-horizons beyond the selected time period. It is pointed by Pesaran and Shin, (1999) that generalized forecast error variance decomposition method shows the proportional contribution in one variable due to innovative shocks stemming in other variables. Table-9 has incorporated results of Variance Decomposition Approach (VDA). According to results, $73.4 \%$ of money demand is explaining by itself, $11.24 \%$ of money demand is explaining by industrial production, $8.67 \%$ of money demand is explaining by income, $4.62 \%$ of money demand is explaining by financial development and $1.98 \%$ of money demand is explaining by exchange rate. The major portion in explaining money demand has industrial production. The ratio of money demand, income, financial development and exchange rate to industrial production is $18.67 \%, 4.4 \%, 1.76 \%$ and $3.99 \%$ respectively. $71.1 \%$ of industrial production is explaining by itself. Similarly, $12.3 \%$ of income is explaining by money demand, $65 \%$ of income is explaining by industrial production, 
$0.4 \%$ of income is explaining by financial development, $8 \%$ of income is explaining by exchange rate and $14.1 \%$ of income is explaining by itself. The innovative shocks in Money demand, industrial production, income and exchange rate are explaining financial development by $25.8 \%, 20.9 \%, 12.8 \%$ and $7 \%$ respectively. $23.2 \%$ of exchange rate is explaining by innovative shocks in money demand and $18.5 \%$ of exchange rate is explaining by industrial production. Similarly, $8 \%$ and $2.7 \%$ of exchange rate is explaining by income and financial development respectively.

Table-9 Variance decomposition Approach

\begin{tabular}{|c|c|c|c|c|c|c|}
\hline \multicolumn{7}{|c|}{ Variance Decomposition of $\ln M 2_{t}$} \\
\hline Period & S.E & $\ln M 2_{t}$ & $\ln i n d p_{t}$ & $\ln y_{t}$ & $\ln f d_{t}$ & $\ln e x r_{t}$ \\
\hline 1 & 0.042506 & 100.0000 & 0.000000 & 0.000000 & 0.000000 & 0.000000 \\
\hline 3 & 0.090657 & 91.88047 & 0.650610 & 3.036622 & 4.378361 & 0.053919 \\
\hline 5 & 0.117078 & 81.86682 & 6.013149 & 6.499269 & 5.580149 & 0.040617 \\
\hline 8 & 0.136343 & 74.88616 & 10.93343 & 8.357095 & 5.064113 & 0.759200 \\
\hline 9 & 0.139874 & 74.00871 & 11.21835 & 8.609626 & 4.817187 & 1.346127 \\
\hline 10 & 0.142818 & 73.46631 & 11.24260 & 8.675862 & 4.625615 & 1.989612 \\
\hline \multicolumn{7}{|c|}{ Variance Decomposition of $\ln i n d p_{t}$} \\
\hline Period & S.E & $\ln M 2_{t}$ & $\ln i n d p_{t}$ & $\ln y_{t}$ & $\ln f d_{t}$ & $\ln e x r_{t}$ \\
\hline 1 & 0.029976 & 1.630093 & 98.36991 & 0.000000 & 0.000000 & 0.000000 \\
\hline 3 & 0.061068 & 10.38079 & 75.12689 & 8.261089 & 2.445608 & 3.785619 \\
\hline 5 & 0.075929 & 14.42621 & 73.21208 & 5.737898 & 2.059338 & 4.564470 \\
\hline 8 & 0.085196 & 17.37238 & 72.16639 & 4.593401 & 1.727240 & 4.140584 \\
\hline 9 & 0.086422 & 18.05233 & 71.71360 & 4.485791 & 1.717581 & 4.030698 \\
\hline 10 & 0.087299 & 18.67801 & 71.15186 & 4.407895 & 1.769018 & 3.993209 \\
\hline \multicolumn{7}{|c|}{ Variance decomposition of $\ln y_{t}$} \\
\hline Period & S.E & $\ln M 2_{t}$ & $\ln i n d p_{t}$ & $\ln y_{t}$ & $\ln f d_{t}$ & $\ln e x r_{t}$ \\
\hline 1 & 0.016313 & 3.235952 & 40.55932 & 56.20473 & 0.000000 & 0.000000 \\
\hline 3 & 0.030588 & 6.304699 & 58.42685 & 29.94602 & 0.129349 & 5.193082 \\
\hline 5 & 0.041113 & 9.686498 & 62.08706 & 19.91841 & 0.362167 & 7.945868 \\
\hline 8 & 0.048076 & 11.72148 & 64.69467 & 14.92908 & 0.347222 & 8.307553 \\
\hline
\end{tabular}




\begin{tabular}{|c|c|c|c|c|c|c|}
\hline 9 & 0.048878 & 12.05615 & 64.99639 & 14.44328 & 0.359759 & 8.144423 \\
\hline 10 & 0.049329 & 12.32881 & 65.05597 & 14.18026 & 0.427632 & 8.007329 \\
\hline \multicolumn{7}{|c|}{ Variance Decomposition of $\ln f d_{t}$} \\
\hline Period & S.E & $\ln M 2_{t}$ & $\ln i n d p_{t}$ & $\ln y_{t}$ & $\ln f d_{t}$ & $\ln e x r_{t}$ \\
\hline 1 & 0.067675 & 40.56538 & 0.756021 & 1.451476 & 57.22712 & 0.000000 \\
\hline 3 & 0.127393 & 38.70112 & 13.39435 & 2.803467 & 42.14277 & 2.958787 \\
\hline 5 & 0.164394 & 31.66813 & 22.06372 & 6.800152 & 37.02224 & 2.445753 \\
\hline 8 & 0.181562 & 27.76449 & 21.56982 & 13.27412 & 33.68156 & 3.710007 \\
\hline 9 & 0.184997 & 26.78530 & 20.99634 & 14.41226 & 32.48161 & 5.324493 \\
\hline 10 & 0.188511 & 25.82402 & 20.91873 & 12.89838 & 31.28218 & 7.076699 \\
\hline \multicolumn{7}{|c|}{ Variance Decomposition of $\ln e x r_{t}$} \\
\hline Period & S.E & $\ln M 2_{t}$ & $\ln i n d p_{t}$ & $\ln y_{t}$ & $\ln f d_{t}$ & $\ln e x r_{t}$ \\
\hline 1 & 0.048492 & 8.478392 & 6.873641 & 15.76132 & 0.882193 & 68.00445 \\
\hline 3 & 0.075194 & 12.66123 & 8.884119 & 10.92278 & 1.908515 & 65.62335 \\
\hline 5 & 0.082587 & 10.95002 & 11.53677 & 9.777628 & 2.856265 & 64.87931 \\
\hline 8 & 0.089104 & 18.41874 & 12.54906 & 9.642270 & 2.675370 & 56.71456 \\
\hline 9 & 0.093448 & 21.27291 & 15.28733 & 8.886444 & 2.719321 & 51.83400 \\
\hline 10 & 0.098208 & 23.29708 & 18.58246 & 8.067355 & 2.770272 & 47.28284 \\
\hline
\end{tabular}

\section{Conclusion and Recommendation:}

This paper has estimated impact of financial development on money demand by incorporating financial development, industrial production, income and exchange rate for Pakistan using time span from 1972 to 2012. Bayer-Hanck combined cointegration and Johansen cointegration approach have been applied to check cointegration among variables because all data series are integrated at $1^{\text {st }}$ difference. Both tests have confirmed cointegration among variables which confirm the long run relation among financial development, industrial production, income and exchange rate. Long run analysis has confirmed significance of all variables especially financial development with positive sign. It means that money demand function is stable in long run. But in short run, only financial development has significant impact on money demand. Lagged ECM has negative insignificant value. It means that in short run, money demand function is not stable. VECM Granger causality has applied to check causality in short and long run. Results revealed 
that bidirectional causality exist among financial development and money demand, and income and industrial production in both short and long run. Unidirectional causal relationship exists between exchange rate to money demand and income in both short run and long run. Government should focus on financial development in both short and long run to control money demand because it has statistical significant impact on money demand in both short run and long run.

\section{References:}

1. Azim, P., Ahmed, N., Ullah, S., Zaman, B. and Zakaria, M. (2010). Demand for money in Pakistan: An ARDL approach. Global Journal of Management and Business Research, 10(9), 76-80

2. Akinlo, E.A., (2006). Stability of money demand in Nigeria: an autoregressive distributes lag approach. J. Pol. Model. 28, 445-452

3. Akinlo, A.E., (2006). The Stability of Money Demand in Nigeria: An Autoregressive Distributed Lag Approach. Journal of Policy Modeling, 28:445-452.

4. Achsani, N.A. (2010). Stability of Money Demand in an Emerging Market Economy: An Error Correction and ARDL Model for Indonesia. Research Journal of International Studies.

5. Ahmed, S. and Md. Ezazul Islam (2007). A Cointegration Analysis of the Demand for Money in Bangladesh. Working Paper Series, Resurch Division, Bangladesh Bank.

6. Bahmani-Oskooee, M. (2001). How Stable is M2 Money Demand Function in Japan? Japan and World Economy, 13, 455-461.

7. Bahmani-Oskooee, M. and Rehman, H (2005). Stability of Money Demand Function in Asian Developing countries. Applied Economics, 37, 773-792.

8. Bahmani-Oskooee, M. and Ng, R. C. W. (2002). Long run Demand for Money in Hong Kong: An Application of the ARDL Model. International Journal of Business and Economics, 1(2): 147-155.

9. Bahmani, S. and Bahmani-Oskooee, M. (2007a). Exchange Rate Volatility and Demand for Money in Iran? An Unpublished Paper, Department of Economics, the University of Wisconsin-Milwaukee, Milwaukee, Wisconsin 53201.

10. Bahmani-Oskooee, M. and Wang, Y. (2007b). How Stable is the Demand for Money in China? Journal of Economic Development, 32(1).

11. Bayer, C. and Hanck, C. (2013). Combining Non-Cointegration Tests. Journal of Time Series Analysis, 34(1), 83-95.

12. Bhatta, R. S. (2011). Stability of demand for money function in Nepal: A cointegration and error correction modeling approach, MPRA Paper No. 41404, University Library of Munich

13. Brand, C. and Cassol, N. (2000). A Money Demand System for Euro Area M3. European Central Bank series Working Paper 0039.

14. Budha, B. (2011). An Empirical analysis of Money Demand Function in Nepal. Economic Review, NRB, Kathmandu, Nepal.

15. Boriss, S., (2007). Money Demand in Estonia. Discussion Papers of DIW Berlin 675, DIW Berlin, German Institute for Economic Research. 
16. Boswijk, P. H. (1994). Testing for Unstable Root in Conditional and Structural Error Correction Models. Journal of Econometrics, 63(1), 37-60

17. Banerjee, A., Dolado, J. and Mestre, R. (1998). Error-Correction Mechanism Tests for Cointegration in A single-Equation Framework. Journal of Time Series Analysis, 19(3), 267-283

18. Bayer, C., and Hanck, C., (2013). Combining Non-CointegrationTests. Journal of Time Series Analysis, 34(1): 83-95

19. Canova, L. (2006). Estimating demand for money in Jamaica. MPRA Paper 1023, University Library of Munich, Germany.

20. Doğru, B., (2013). Dynamic Analysis of Money Demand Function: Case of Turkey. MPRA Paper 48402, University Library of Munich, Germany.

21. Dreger, C. and Wolters, J. (2014). Unconventional Monetary Policy and Money Demand. DIW Berlin, German Institute for Economic Research series, 1382.

22. Dickey, D. A. and W. A. Fuller, (1981). Likelihood ratio statistics for autoregressive time series with a unit root. Econometrica, 49, 1057-1079

23. Elliott, G. R., Thomas, J. and J. H. Stock, (1996). Efficient tests for an autoregressive unit root. Econometrica, 64, 813-836

24. Engle, R. F. and Granger, C. W. (1987). Co-integration and error correction: representation, estimation and testing. Econometrica: Journal of the Econometric Society, 251-276

25. Friedman, M., (1987) Quantity Theory of Money. In J. Eatwell, M. Milgate, and P. Newman (eds.) The New Palgrave: A Dictionary of Economics. Vol. 4. London: The Macmillan Press Germany.

26. Dumitru, I., (2002). "Money Demand in Romania," MPRA Paper 10629, University Library of Munich, Germany.

27. Alfredo, G. H. and Leonel, C. (2006). Empirical Evidence for A Money Demand Function: A Panel Data Analysis of 27 Countries in 1988-98. Applied Econometrics and International Development, Euro-American Association of Economic Development, vol. 6(1). 51-58

28. Hamori, N. and S. Hamori (1999). Stability of Money Demand Function in Germany. Applied Economics Letters, 6: 329-332

29. Hafer, R. W. and Jansen D. W. (1991). the demand for money in the United States: Evidence from Cointegration test. Journal of money, credit and banking, 23(2): 155-168.

30. Halicioglu, F. and Ugur, M. (2005). On Stability of Money Demand for a Developing OECD Country, Global Business and Economic Review, 7(8).

31. Hussain, Z et.al (2006) Demand for Money in Pakistan. International Research Journal of Finance and Economics. Issue, 5, 209-218

32. Tillers, I. (2004). Money Demand in Latvia. Working Papers 2004/03, Latvijas Banka.

33. Iyoboyi, M. and Pedro, L. M. (2013). The Demand for Money in Nigeria: Evidence from Bounds Testing Approach. Business and Economics Journal, Vol. 2013 Issue 1, p1

34. Inoue, T. and Hamori, S. (2009). An Empirical Analysis of the Money Demand Function in India, Economics Bulletin, AccessEcon, vol. 29(2), pages 1224-1245.

35. Johansen, S. (1991). Estimation and Hypothesis Testing of Cointegration Vectors in Gaussian Vector Autoregressive Model. Econometrica: Journal of the Econometric Society, 1551-1580 
36. Judd, J., and Scadding, J. (1982). The Search for a Stable Money Demand Function: A Survey of the Post-1973 Literature. Journal of Economic Literature. September

37. Kumar, S. and Manoka, B., (2008). Testing the Stability of Demand for Money in Tonga. MPRA Paper 19300, University Library of Munich, Germany.

38. Khatiwada, Y.R. (1997). Estimating the Money Demand in Nepal: Some Empirical Issues. Economics Review, Occasional Paper, NRB No. 9.

39. Kahrel R.M. and Koirala, T. P. (2010). Modelling Demand for Money in Nepal. NRB Working Paper.

40. George, K. (2002). Evidence on the demand for money function in Uganda. UNICEF Zimbabwe Working Paper No. 2002-01

41. Kirill, A. S (2012). Estimation of the Money Demand Function in Russia, Journal of the New Economic Association, 18(2): 89-99

42. Khan A. H. and Ali, S. S. (1997) The Demand for Money in Pakistan: An Application of Cointegration and Error Correction Modeling. Savings and Development, No. 1

43. Lumas, G.S. and Mehra, Y.P. (1976). "The Stability of the Demand for money function: The Evidence from Quarterly data". The Review of Economics and Statistics, 58(4), 463468.

44. Mangla, I.U. (1979). An Annual Money Demand Function for Pakistan: Some Further Results. Pakistan Development Review, Vol. XVII, No.1, spring

45. Ng, S. and P. Perron, (2001), 'Lag length selection and the construction of unit root test with good size and power', Econometrica, 69, 1519-1554

46. Omer, M. (2010). "Stability of Money Demand Function in Pakistan". SPB Working Paper Series.

47. Singh, P. and Pandey, M. K., (2010). Financial Innovation and Stability of Money Demand Function in Post-reform period in India. Economics Bulletin, Access Econ, vol. 30(4), pages 2895-2905.

48. Phillips, P. C. and Ouliaris. S. (1990). Asymptotic Properties of Residual Based Tests for Cintegration. Economatrica: Journal of Econometric Society, 165-193

49. Phillips, P. C. B. and Perron, P. (1988), 'Testing for a unit root in time series regressions'. Biometrika, 75, 335-346.

50. Qayyum, A. (2005). Modelling the Demand for Money in Pakistan. The Pakistan Development Review, 44(3), 233-252.

51. Qayyum, A. (1994-98) Error Correction Model of Demand for Money in Pakistan, Kashmir Economic Review, No. 1-2.

52. Sahin, A., (2013). "Estimating Money Demand Function by a Smooth Transition Regression Model: An Evidence for Turkey". MPRA Paper 46851, University Library of Munich, Germany.

53. Samreth, S., (2008). Estimating Money Demand Function in Cambodia: ARDL Approach," MPRA Paper 16274, University Library of Munich, Germany, revised Jun 2009.

54. Shahbaz, M. and Rahman, M. M., (2012). The Dynamic of Financial Development, Imports, Foreign Direct Investment and Economic Growth: Cointegration and Causality Analysis in Pakistan, Global Business Review, 13(2), 201-219

55. Sriram, S. S. (2001). A Survey of Recent Empirical Money Demand Studies. IMF Staff Papers, 47(3), 334-365 
56. Sarwar, H., Hussian, Z. and Awan, M. S. (2011). Money Demand Functions for Pakistan (Divisia Approach), MPRA Paper 34361, University Library of Munich, Germany.

57. Tang, C. F., (2007). The stability of money demand function in Japan: Evidence from rolling cointegration approach. MPRA paper 19807, University Library of Munich, Germany.

58. Taylor, M.P. (1993). Modeling the Demand for UK Broad Money. The Review of Economics and Statistics, 75(1), 112-117. 